\title{
The Mediating Role of Job Satisfaction in the Relationship Between Quality of Work Life and Turnover: The Moderating Role of Gender
}

\author{
Derya KARA iD a Nihan POTAS iD b Frat SEYHAN iD c \\ a Ankara Hacı Bayram Veli University, Faculty of Economics and Administrative Sciences, Ankara, Turkey. derya.sivuk@hbv.edu.tr \\ b Ankara Hacı Bayram Veli University, Faculty of Economics and Administrative Sciences, Ankara, Turkey. nihan.potas@hbv.edu.tr \\ c University of Health Sciences, Department of Management and Organization, Health Institutions Management, Istanbul, Turkey. \\ firat.seyhan@sbu.edu.tr
}

\begin{tabular}{|c|c|}
\hline ARTICLE INFO & ABSTRACT \\
\hline Kеуш & $\begin{array}{l}\text { Purpose - The purpose of this study is to examine-using a moderation role of gender- the mediating } \\
\text { role of job satisfaction between quality of work life and turnover intention. }\end{array}$ \\
\hline $\begin{array}{l}\text { Quality of work life } \\
\text { Turnover } \\
\text { Healthcare employees and }\end{array}$ & $\begin{array}{l}\text { Design/methodology/approach - Data were collected from healthcare organizations employees (n } \\
=325 \text { ) in Ankara. The hypotheses were tested using The Mediation Analysis and Moderated } \\
\text { Mediation Analysis. The questionnaire method, which is the primary data collection tool, was } \\
\text { applied for the study. Survey data were analyzed using SPSS program. }\end{array}$ \\
\hline ge & $\begin{array}{l}\text { Findings - The mediation analysis showed that the job satisfaction has mediating effect on the } \\
\text { relationship between quality of work life and turnover intention of employees. Second, Moderated }\end{array}$ \\
\hline $\begin{array}{l}\text { Received } 7 \text { June } 2020 \\
\text { Revised } 1 \text { September } 2020 \\
\text { Accepted } 17 \text { September } 2020\end{array}$ & $\begin{array}{l}\text { Mediation Analysis showed that gender moderated the relation between quality of work life-job } \\
\text { satisfaction and job satisfaction-turnover intention. When job satisfaction increases, the turnover } \\
\text { intention of men is much higher than women. Finally, gender didn't moderate the relation between } \\
\text { the quality of work life and turnover. }\end{array}$ \\
\hline $\begin{array}{l}\text { Article Classification: } \\
\text { Research Article }\end{array}$ & $\begin{array}{l}\text { Discussion - The participation of female employees in the workforce has recently become an } \\
\text { important issue. It is important to understand the relationship between the quality of work life and } \\
\text { job satisfaction, and its effects on turnover intention, due to the woman's responsibilities regarding } \\
\text { home and family. In this context, managers are recommended to make some arrangements in the } \\
\text { organization to increase the job satisfaction and quality of life of female employees. With these } \\
\text { arrangements, employee turnover intention will decrease and the organization will be more } \\
\text { successful. }\end{array}$ \\
\hline
\end{tabular}

\section{Introduction}

The working conditions of healthcare professionals are changing rapidly and adaptation to this change becomes difficult. The social and health sector is one of the fastest and biggest growing employers in the world with 234 million employees, especially female (Boniol et al., 2019: 2). The healthcare employees labor force participation rate was 1.016.401 in 2018 (Health Statistics Yearbook, 2018). According to TUIK 2018 data, the labor force participation rate of men $71.5 \%$, while the labor force participation rate of women as $33.3 \%$ in Turkey. According to the Turkey ranks 136 among 153 countries in economic participation (World Economic Forum, 2020). In Turkey, the reasons of low female labour-force participation are lower rates of female adult literacy (Kılıç, 2008); culture (Hayo \& Caris, 2013); education (Dayioglu, 2000; Goksel, 2013); the role of housework (Özar \& Günlük-Şenesen, 1998; Dedeoglu, 2010); traditional and social roles (Goksel, 2012; O'Neil \& Bilgin, 2013;). Females' have more responsibilities related child care and home in Turkey. It causes them to be more passive than man in public space. With a higher participation of women in the labour market, economy can use more productive its potential (Karaalp-Orhan, 2017: 304).

It is important to understand that participation of female employees to labour force and the relationship among job outcomes such as job satisfaction, quality of work life needs and how these constructs effect employees' turnover intentions especially the healthcare organizations. Despite numerous studies that have been conducted (as seen below), gender issue has gap in this area, especially in Turkey. Therefore, using a moderation role of gender, we argued that the mediating role of job satisfaction between turnover intention and quality of work life. Futhermore, the study used some demographic variables such as education situation,

\section{Önerilen Atıf/Suggested Citation}

Kara, D., Potas, N., Seyhan, F. (2020). The Mediating Role of Job Satisfaction in the Relationship Between Quality of Work Life and Turnover: The Moderating Role of Gender, Journal of Business Research-Turk, 12 (3), 3027-3041. 
marital status, and working hour in order to examine the existing differences between the two gender groups in the all constructs.

\section{Literature Review}

The following section provides information about job satisfaction, quality of work life and turnover intention of employees.

\subsection{Quality of Work Life}

Quality of work life has become a prerequisite for the efficiency and success of organizations (Sandrick, 2003:6). The quality of working life, which contributes to increasing the performance of working people in the workplace, is of great importance for a business to perform its activities correctly. Studies (Saraji \& Dargahi, 2006; Almalki et al, 2012a) showed that employees weren't satisfied from their work life. Especially considering the amount of time and energy spent by the employees at their jobs, ensuring that their employees are satisfied with their time at the job site should be among the primary objectives of the enterprises. When employees were dissatisfied of their jobs turnover intention increase. Studies (Mosadeghrad et al, 2011; Almalki et al, 2012b; Lee et al., 2013; Zhao et al., 2013; Mohamed Elshahat et al, 2019) showed that QWL was negatively associated with turnover intentions. Given this, we propose the following hypotheses that will be subjected to an empirical test:

$\mathrm{H}_{1}$ : "Quality of work life influences the turnover intention of employees."

\subsection{Job Satisfaction}

Job satisfaction contributes to the competitiveness of organizations and increases job performance (Bashor \& Purnama, 2017: 156; Thakur \& Sharma, 2019: 328). The mediating role of job satiscaction is investigated in antecedents of organizational commitment (Lok \& Crawford, 2001); in stressful work, citizenship behaviour and intention to leave the organization in a high turnover environment (Paillé, 2011); in job training satisfaction and turnover intentions (Huang \& Su, 2016); in work stress and turnover intentions among hospital physicians (Tziner et al., 2015); in high amount of compensation and employees intend to leave work (Rubel \& Kee, 2015); in life satisfaction (Newman et al., 2015). Studies (Tziner et al., 2015; Chen et al., 2019) found that job satisfaction mediated the relationship between burnout and turnover intentions. Thus, our study proposes to test the following hypothesis:

$\mathrm{H}_{2}$ : “The job satisfaction has mediating effect on the relationship between quality of work life and turnover intention of employees."

The mediating model contains two relationships. The first relationship is quality of work life influences the job satisfaction. When related literature examined, researchers (Nuari, 2016; Jahanbani et al., 2018; Srivastava et al., 2019) found the positive association between quality of work life and job satisfaction in healthcare organizations. From this evaluation;

$\mathrm{H}_{2 \mathrm{a}}$ : "Quality of work life influences job satisfaction of employees."

Second relationship is job satisfaction influences turnover intention. Researchers (Tziner et al., 2015; Lu et al., 2017; Chen et al., 2019; Li et al., 2019; Al Sabei et al., 2020) found that turnover intention was negatively related to job satisfaction in healthcare organizatations. Namely, job dissatisfaction is a strong predictor for employees to intend to leave (Steinmetz et al., 2014: 9). From this evaluation, we propose to test the following hypothesis: $\mathrm{H}_{2 \mathrm{~b}}:$ " Job satisfaction influences turnover intention of employees."

\subsection{Gender}

The moderating role of gender has gained importance in organizational outcomes sucha as job satisfaction, turnover intention and quality of work life of employees in organizations, especially healthcare organizations. We propose to test the third hypothesis:

$\mathrm{H}_{3}$ : “The gender moderates the mediation of job satisfaction on quality of work life and turnover intention of employees."

The previous moderator hypothesis contains three sub-hypothesis. First, gender moderates the relation between quality of work life and job satisfaction. While some researchers (Kasraie et al., 2014; Miao et al, 2017; Carrillo-García et al., 2017) found that job satisfaction of female employees is higher than male employees, some researchers (Black \& Holden, 1998; Tarcan et al., 2017) found that male employees job satisfaction is higher than female employees in the healthcare organizations. On the other hand, studies (Mobaraki et al., 
D. Kara - N. Potas - F. Seyhan 12/3 (2020) 3027-3041

2017) showed that gender did not have a significant effect on quality of work life and job satisfaction. Female satisfaction can be regarded with their low expectations regarding work conditions (Oh \& Kim, 2019: 6). From this evaluation;

$\mathrm{H}_{3 \mathrm{a}}$ : "The gender moderates the relation between quality of work life and job satisfaction of employees."

Second, gender moderates the relation between quality of work life and turnover intentions. Researchers (Moradi et al., 2014; Almalki et al., 2012a; Heidari-Rafat et al., 2010) found that female employees had a higher quality of work life mean score than male nurses. However, the study conducted by Moradi, Maghaminejad \& Azizi-Fini (2014) showed that the difference was not significant. Other studies have found no association between gender and work related quality of life (Hsu \& Kernohan, 2006; Sirgy et al., 2001). From this evaluation;

$\mathrm{H}_{3 \mathrm{~b}}$ : "The gender moderates the relation between the quality of work life and turnover intention of employees."

Third, gender moderates the relation between job satisfaction and turnover intentions. Previous studies have examined gender role in effective job satisfaction and turnover intention and found mixed findings. While studies (Liu et al., 2019; Chao et al., 2015) showed that female employees were dissatisfied and had turnover intention, other studies (Heinen et al., 2013; Oh \& Kim, 2019) showed that males were more likely than females to intend a turnover. Steinmetz et al.(2014) found that being a woman significantly reduces the intention to stay in the health workforce. From this evaluation;

$\mathrm{H}_{3 \mathrm{c}}$ : "The gender moderates the relation between the job satisfaction and turnover intention of employees."

Women and men differ in gender roles. Traditional individuals believe that the role of a woman is at home and the role of a man is in the public sphere (Corrigall \& Konrad, 2007: 847). Boles, Johnston and Hair (1997) showed that the conflict between the work and home domains is highly related to important workplace attitudes and perceptions and suggests that work-family conflict should be included in models examining employee response to the effects of stress.

\section{Theoretical Model and Hypotheses Formulation}

The research model of this study was developed based on the existing literature. This model depicts the relationship among job satisfaction, quality of work life and how these constructs effect employees' turnover intentions in the healthcare organizations. The conceptual framework of the study is presented in Figure.1

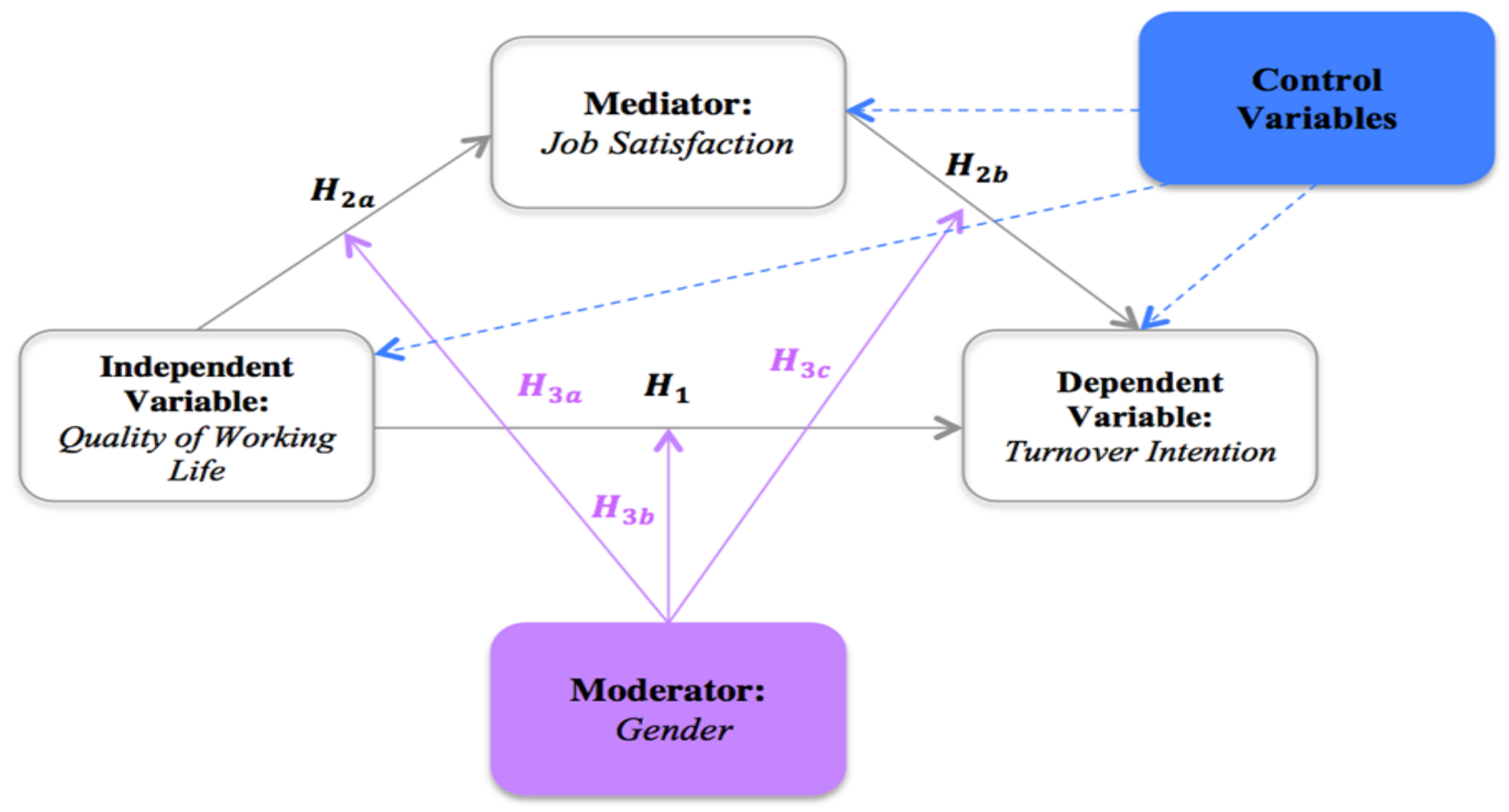

Figure 1. The Conceptual Framework of the Study 


\section{Research Methodology}

\section{Instrument development}

The questionnaire was filled out by employees using face-to-face interview technique. The survey questionnaire consisted of four parts. In the first part; there are questions regarding the demographic characteristics of the employees. In the second part; Job Satisfaction was measured using a 5-item developed by Hackman \& Oldham (1975) and adopted by Basim \& Şeşen (2009). 5 items were captured using 5-point Likert scales varying from "I do not agree at all" (1) to "I agree completely" (5). Third part of the survey measured Quality of Work Life of employees using a 23-item measure developed by Van Laar vd. (2007) and adopted by Akar \& Üstüner (2017). The fourth part of the survey measured Turnover Intention using a 3-item measure developed by Mobley, Horner and Hollingsworth (1978)using 5-point Likert type scales from "I do not agree at all" (1) to "I agree completely" (5).

\section{Data collection and sample size}

Data collected from employees of Education Research Hospital in Ankara, Turkey from September 2019 through November 2019. The data comprise a total of 2095 personnel, including 377 physicians, 764 nurses, 33 midwives, 263 health technicians, 563 officers and 95 other professional groups (biologists, pharmacists, child development specialists, dieticians, psychologists, etc.) work in the hospital. In the research, stratified sampling, one of the probability sampling methods, was used. According to $5 \%$ margin of error, the total sample was calculated as 325 .

Table 1. Stratified Sampling Table

\begin{tabular}{|c|c|c|c|c|}
\hline $\begin{array}{l}\text { Stratify } \\
\text { Number }\end{array}$ & Stratify Name & $\begin{array}{l}\text { Employees } \\
\text { Number }\end{array}$ & Stratify Weight & $\begin{array}{c}\text { Number of } \\
\text { Employees Sampled }\end{array}$ \\
\hline 1 & Doctor & 377 & $377 / 2095=0.18$ & 58 \\
\hline 2 & Nurse & 764 & $764 / 2095=0.36$ & 119 \\
\hline 3 & Midwife & 33 & $33 / 2095=0.02$ & 5 \\
\hline 4 & Health Technician & 263 & $263 / 2095=0.13$ & 41 \\
\hline 5 & Officer & 563 & $563 / 2095=0.27$ & 87 \\
\hline \multirow[t]{2}{*}{6} & Other & 95 & $95 / 2095=0.05$ & 15 \\
\hline & Total & 2095 & 1 & 325 \\
\hline
\end{tabular}

\section{Statistical techniques}

Statistical analyses were performed using R version 3.5.3, SPSS version 23.0. Moderated mediation analyses the influence of the job satisfaction variable on the mediated relationship between the quality of working life and the turnover intention variables. Also, the effect of the mediator is moderated by the gender variable and whether the control variables effect the each path. The moderated mediation analysis was set-up according to the hypothesis model (Figure 1). M: job satisfaction is the mediator and $\mathrm{W}$ : gender is the moderator. $\mathrm{M}$ mediates the relationship between a predictor, $X$ : quality of working life, an outcome $Y$ : turnover intention and $\mathrm{W}$ moderates the relationship between $\mathrm{X} \rightarrow \mathrm{Y}, \mathrm{M} \rightarrow \mathrm{Y}, \mathrm{X} \rightarrow \mathrm{M}$, and $\mathrm{X}+\mathrm{M} \rightarrow \mathrm{Y}$. All of the assumptions of the multiple regressions were checked: the linear relationship between the independent and dependent variables, the mean of residuals is zero, normality of residuals, no multicollinearity, no.autocorrelation of residuals and homoscedasticity of residuals or equal variance. The point-biserial coefficient of correlation and Pearson's coefficient of correlation were used to evaluate the relationship between each variable. P-value was two-sided and differences were evaluated significant levels at .05 and .01.

\section{Data Analysis}

The respondents were mostly woman (61.2\%), married (70.5\%). In terms of education status mostly bachelor degree (49.5), $36.3 \%$ of the participants was nurse and $45.8 \%$ of the participants have worked in day shift. The descriptive analysis of the demographic composition of the respondents is summarized in Table 2. 
D. Kara - N. Potas - F. Seyhan 12/3 (2020) 3027-3041

Table 2. Descriptive Statistics of Categorical Variables $(n=325)$

\begin{tabular}{llllll}
\hline \multirow{2}{*}{ Variables } & Categories & $\mathbf{n}$ & $\mathbf{\%}$ & Median & IQR \\
\hline \multirow{4}{*}{ Gender } & Man & 126 & 38.8 & 2.00 & $1.00-2.00$ \\
& Woman & 199 & 61.2 & & \\
Education status status & Married & 229 & 70.5 & 1.00 & $1.00-2.00$ \\
& Single & 87 & 26.8 & & \\
& Other & 9 & 2.8 & & \\
& High School & 15 & 4.6 & 3.00 & \multirow{2}{*}{$3.00-4.00$} \\
& Associate & 53 & 16.3 & & \\
Occupation & 161 & 49.5 & & \\
& Machelor & 51 & 15.7 & & \\
& Doctorate & 45 & 13.8 & & \\
& Doctor & 58 & 17.8 & 2.00 & $2.00-5.00$ \\
& Nurse & 119 & 36.6 & & \\
& Midwife & 5 & 1.5 & & \\
& Health Technician & 41 & 12.6 & & \\
& Officer & 87 & 26.8 & & \\
& Other & 15 & 4.6 & & \\
Working Hours & Day shift & 149 & 45.8 & 2.00 & $1.00-2.00$ \\
& Day and night shifts & 124 & 38.2 & & \\
& Night shift & 52 & 16.0 & & \\
\hline
\end{tabular}

IQR:Interquartile Range

\section{Reliability Test}

This study was used a coefficient alpha to explore the internal reliability of each variable. Cronbach alpha showed that all factors have internal reliability as their alpha values are greater than 0.70 .

Table 3. Reliability Assesment

\begin{tabular}{|l|c|c|}
\hline Variables & Items & Cronbach's Alpha Value \\
\hline Job Satisfaction & 5 & 0.87 \\
\hline Quality of Work Life & 23 & 0.92 \\
\hline Turnover Intention & 3 & 0.94 \\
\hline
\end{tabular}




\section{Correlation Analysis}

Table 4. Mean, Standart Deviation, Point-Biserial Correlations and Pearson Correlations amon variables $(n=325)\left(p^{*}<.05, p^{* *}<.01\right)$

\begin{tabular}{|c|c|c|c|c|c|c|c|c|c|c|c|c|c|}
\hline Variables & $\overline{\mathbf{x}}$ & $\mathbf{s}$ & 1 & 2 & 3 & 4 & 5 & 6 & 7 & 8 & 9 & 10 & 11 \\
\hline Gender & 1.610 & .488 & 1 & & & & & & & & & & \\
\hline Age & 36.418 & 8.988 & .024 & 1 & & & & & & & & & \\
\hline Marital status & 1.320 & .524 & -.016 & $-.139^{*}$ & 1 & & & & & & & & \\
\hline Education status & 3.180 & 1.015 & -.103 & .063 & -.074 & 1 & & & & & & & \\
\hline Occupation & 3.020 & 1.627 & $-.216^{* *}$ & .015 & -.032 & $-.593^{* *}$ & 1 & & & & & & \\
\hline Working Hours & 1.70 & .729 & $.238^{* *}$ & .024 & .011 & .051 & $-.300^{* *}$ & 1 & & & & & \\
\hline $\begin{array}{l}\text { Working } \\
\text { Experience }\end{array}$ & 14.495 & 7.900 & -.050 & $.718^{* *}$ & $-.230^{* *}$ & .080 & -.052 & -.006 & 1 & & & & \\
\hline Income & $\begin{array}{l}6752.32 \\
3\end{array}$ & $\begin{array}{l}5151.3 \\
57\end{array}$ & $-.239^{* x}$ & .059 & -.043 & $.639^{* *}$ & $-.576^{* *}$ & -.012 & $.173^{* *}$ & 1 & & & \\
\hline Job Satisfaction & 2.710 & .931 & $-.169^{* * *}$ & .007 & .032 & -.044 & $.146^{* *}$ & $-.259^{* *}$ & .039 & .073 & 1 & & \\
\hline $\begin{array}{l}\text { Turnover } \\
\text { Intention }\end{array}$ & 3.317 & 1.140 & $.228^{* *}$ & .038 & $-.193^{* *}$ & $.304^{* *}$ & $-.364^{* *}$ & $.323^{* *}$ & .054 & $.123^{*}$ & $-.506^{* *}$ & 1 & \\
\hline $\begin{array}{l}\text { Quality of } \\
\text { Working Life }\end{array}$ & 2.733 & .435 & -.036 & -.036 & -.062 & .002 & .058 & $-.239^{* *}$ & -.040 & .026 & $.503^{* *}$ & $-.243^{* *} 1$ & 1 \\
\hline
\end{tabular}

From Table 4 the correlation between gender, age, marital status, education status, occupation, working hours, working experince, income, job satisfaction, turnover intention and quality of working life were shown. Over all, working experince - age, income- education status, quality of working life- job satisfaction have significant, positive and high correlations $(p<.01)$. Occupation-education status, income-occupation and turnover intention- job satisfaction have significant, negative and high correlations $(p<.01)$. Occupationeducation status, income-occupation correlated negatively because the coding of the occupation variables has not a specific order.

Turnover intention-education status and turnover intention- working hours have significant correlations $(p<.01)$ and their correlations are positive and moderate. Gender-working hours, gender-turnover intention, job satisfaction-occupation and income- working experince have significant correlations $(p<.01)$ and their correlations are positive and low $(0.146<\rho<0.238)$. Gender-occupation, income- gender, gender- job satisfaction,working experince- marital status, turnover intention-marital status, working hours- occupation, job satisfaction- working hours, quality of working life- working hours and quality of working life- turnover intention have significant correlations $(p<.01)$ and their correlations are negative and low $(-0.300<\rho<-0.169)$. Turnover intention- occupation has significant, negative and moderate correlations $(p<.01)$.

\section{Mediation Analysis}

Mediation Analysis results of the study is summarized in Table 5. 
D. Kara - N. Potas - F. Seyhan 12/3 (2020) 3027-3041

Table 5. Results of Simple Mediation Analysis

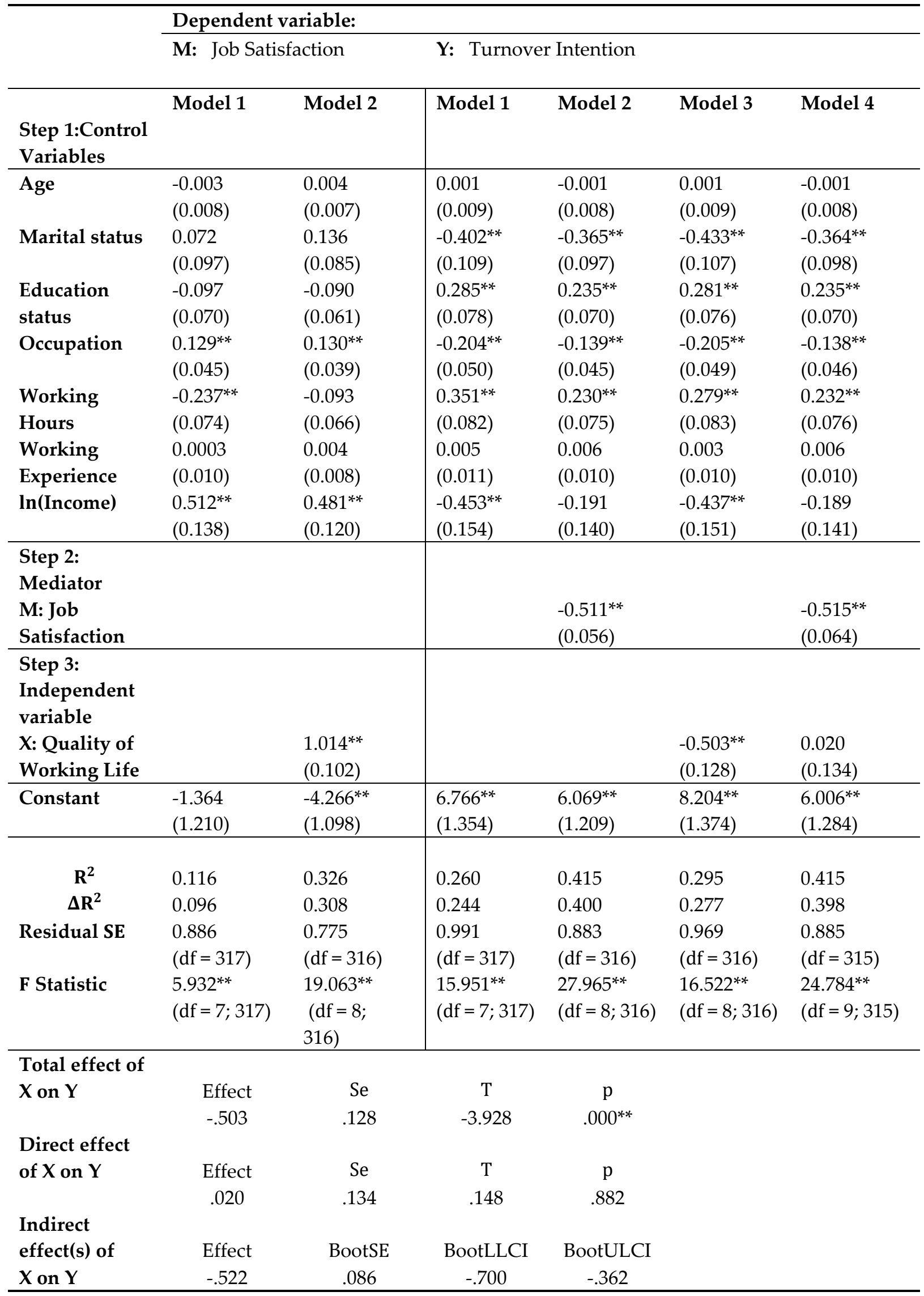

$p^{*}<.05, p^{* *}<.01 ;$ BootSE = Bootstrap Standart Error, BootLLCI = Bootstrap Lower Limit of Confidence Interval, BootULCI= Bootstrap Upper Limit of Confidence Interval; Bootstrap Sample Size $=10^{4}$; (Sobel test $=-6.722, p<0.001$ )

Firstly, three sets of regressions $\mathrm{X} \rightarrow \mathrm{Y}, \mathrm{X} \rightarrow \mathrm{M}$, and $\mathrm{X}+\mathrm{M} \rightarrow \mathrm{Y}$ were tested by using meditation analysis 
D. Kara - N. Potas - F. Seyhan 12/3 (2020) 3027-3041

$\mathrm{X}=$ Quality of Working Life is predicting $\mathrm{Y}=$ Turnover Intention. The model $3(F=16.522, \mathrm{df}=8 ; 316, p<0.01)$ and the coefficient of Quality of Working Life, marital status, education status, occupation, working hours and $\ln$ (Income) are statistically significant.

$X=$ Quality of Working Life is predicting $\mathrm{M}=\mathrm{Job}$ Satisfaction. The model $2(F=19.063, d f=8 ; 316, p<0.01)$ and the coefficient of Quality of Working Life, occupation and $\ln$ (Income) are statistically significant.

$X=$ Quality of Working Life, $M=$ Job Satisfaction are predicting $Y=$ Turnover Intention. The coefficient of Job Satisfaction, marital status, education status, occupation and working hours are statistically significant, on the other hand the coefficient of Quality of Working Life is not statistically significant, also $\mathrm{X}+\mathrm{M} \rightarrow \mathrm{Y}$ model 4 is statistically significant $(F=24.784, d f=9 ; 315, p<0.01)$. It shows that three conditions are met, and then full mediation is supported. The goal of mediation analysis is to obtain this direct effect if it is not statistically significant. It is also not significant as well $(t=0.148, p=0.882)$. The Sobel test, to tell you that whether the indirect effect of the independent variable on the dependent variable through the mediator variable is significant. According to Sobel test results shows that the mediator variable is statistically significant (Sobel test $=-6.722$, $p<0.001)$. It means that the indirect effect is statistically different from zero. The bootstrapping results were also confirmed the Sodel test results. The confidence interval of the bootstrapping is excluding the zero. 
D. Kara - N. Potas - F. Seyhan 12/3 (2020) 3027-3041

Moderated Mediation Analysis

Moderated Mediation Analysis results of the study are summarized in Table 6.

Table 6. Results of Moderated Mediation Analysis

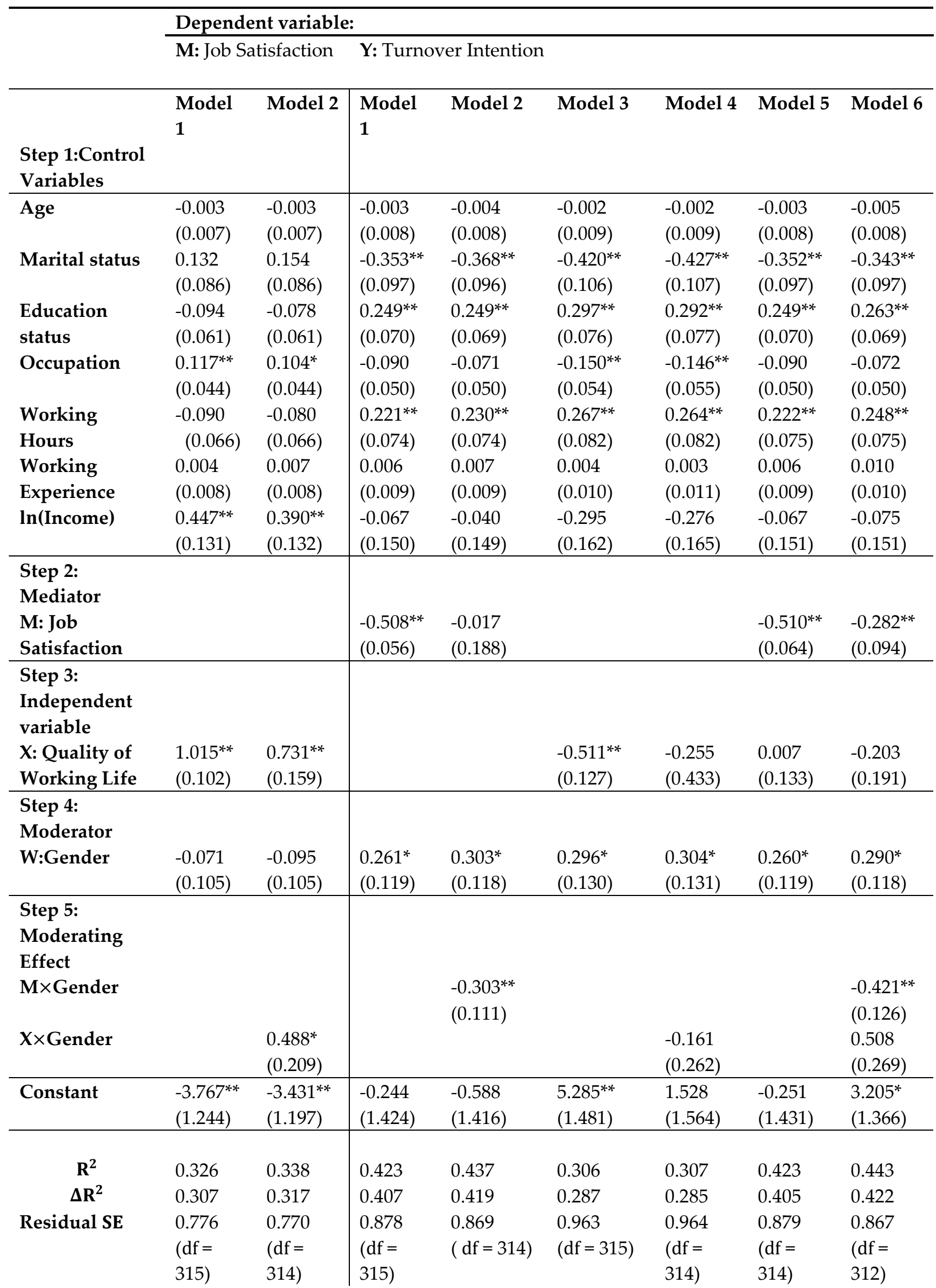


D. Kara - N. Potas - F. Seyhan 12/3 (2020) 3027-3041

\begin{tabular}{lll|llllll} 
F Statistic & $16.966^{* *}$ & $16.028^{* *}$ & $25.695^{* *}$ & $24.351^{* *}$ & $15.456^{* *}$ & $13.921^{* *}$ & $23.053^{* *}$ & $20.720^{* *}$ \\
& $(\mathrm{df}=9 ;$ & $(\mathrm{df}=10 ;$ & $(\mathrm{df}=9 ;$ & $(\mathrm{df}=10 ;$ & $(\mathrm{df}=9 ;$ & $(\mathrm{df}=10 ;$ & $(\mathrm{df}=10 ;$ & $(\mathrm{df}=12 ;$ \\
& $315)$ & $314)$ & $315)$ & $314)$ & $315)$ & $314)$ & $314)$ & $312)$ \\
\hline
\end{tabular}

\section{Conditional direct effect(s) of $\mathrm{X}$ on $\mathrm{Y}$}

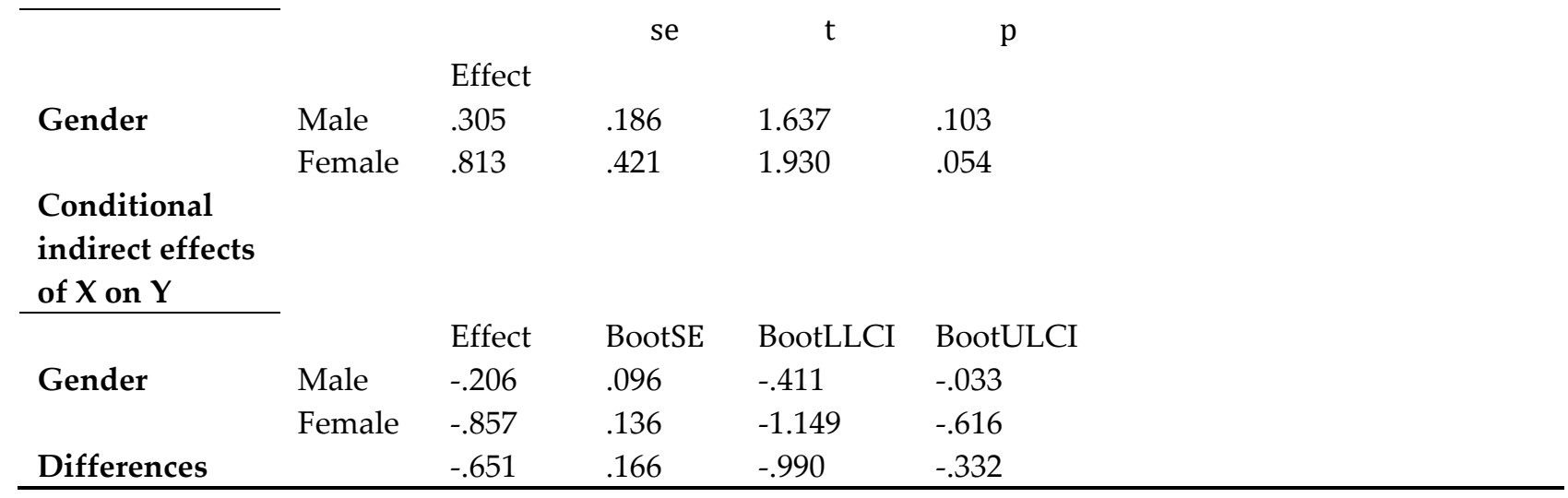

$p^{*}<.05, p^{* *}<.01 ; \quad$ BootSE $=$ Bootstrap Standart Error, BootLLCI $=$ Bootstrap Lower Limit of Confidence Interval, BootULCI= Bootstrap Upper Limit of Confidence Interval; Bootstrap Sample Size $=10^{4}$

$\mathrm{X}=$ Quality of Working Life, $\mathrm{W}=$ Gender and $\mathrm{X} \times \mathrm{W}=$ interaction term are predicting $\mathrm{Y}=$ Turnover Intention. The model $4(F=13.921, d f=10 ; 314, \mathrm{p}<0.001)$ and the coefficient of gender, marital status, education status, occupation and working hours are statistically significant. The interaction term between gender and Quality of Working Life is not significant $(\beta=-0.161, p>0.05)$. Moderation could not be examined how male and female influence the strength of the relationship between Quality of Working Life to Turnover Intention.

$\mathrm{X}=$ Quality of Working Life, $\mathrm{W}=$ Gender and $\mathrm{X} \times \mathrm{W}=$ interaction term are predicting $\mathrm{M}=$ Job Satisfaction. The model $2(F=16.028, d f=10 ; 314, p<0.01)$ and the coefficient of Quality of Working Life, occupation and $\ln$ (Income) are statistically significant. The interaction term between gender and Quality of Working Life is significant as well $(\beta=0.488, p<0.05)$.

$\mathrm{M}=$ Job Satisfaction, $\mathrm{W}=$ Gender and $\mathrm{M} \times \mathrm{W}=$ interaction term are predicting $\mathrm{Y}=$ Turnover Intention. The model $2(F=24.695, d f=10 ; 314, p<0.01)$ and the coefficient of gender, marital status, education status and working hours are statistically significant. The interaction term between gender and Job Satisfaction is also significant $(\beta=-0.303, p<0.01)$. The results of the moderation effect shown in figure 2 .

$\mathrm{X}=$ Quality of Working Life, $\mathrm{M}=$ Job Satisfaction, $\mathrm{W}=$ Gender, $\mathrm{X} \times \mathrm{W}, \mathrm{M} \times \mathrm{W}$ ar predicting $\mathrm{Y}=$ Turnover Intention. The coefficient of Job Satisfaction, gender, marital status, education status, occupation and working hours are statistically significant, on the other hand the coefficient of Quality of Working Life is not statistically significant, also the model 6 is statistically significant $(F=20.720, d f=12 ; 312, p<0.01)$. The interaction term between gender and Job Satisfaction is also significant $(\beta=-0.421, p<0.01)$. The interaction term between gender and Quality of Working Life is not significant $(\beta=0.508, p>0.05)$. The bootstrapping results showed that the confidence interval of the bootstrapping is excluding the zero in both males and females. Even if both indirect effects of male and female are significant, the indirect effect of females is stronger $(-0.857)$ and the indirect effect of males is weaker (-0.206). 


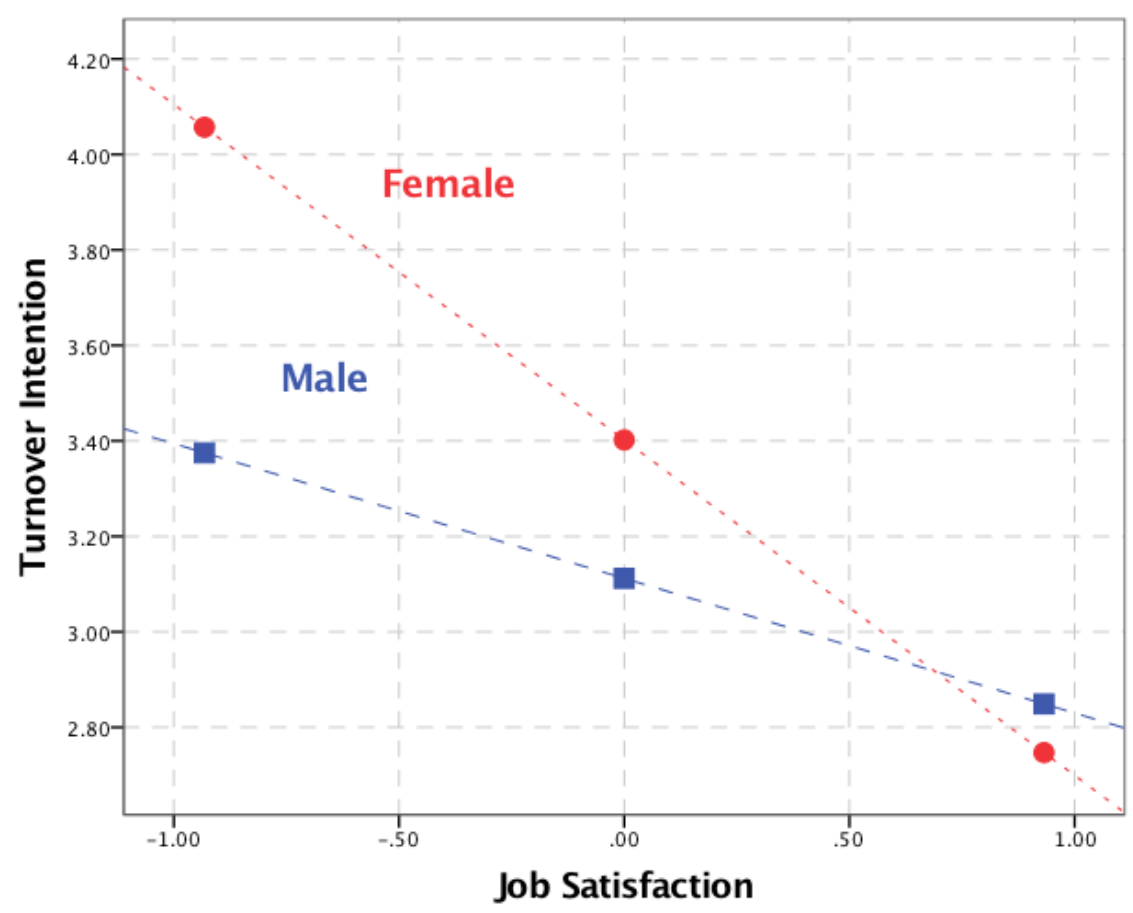

Figure 2. Moderating Effects of Job Satisfaction and Gender on Turnover Intention

The simple slope plot showed that job satisfaction decreases, the turnover intention is much stronger in females (simple slope $=0.813, t=1.930, p<0.01$ ). However, even if job satisfaction increases, the turnover intention is strong in males (simple slope $=0.305, t=1.637, p<0.01$ ).

\section{Discussion and Conclusion}

Healthcare organizations are units where complex uncertainties occur more than other units (Kaitelidou et al. 2012: 571). In this context, employees who feel peaceful in the institution they work and perceive a positive organizational climate contribute to the organization.

The mediation analysis are conducted in this study. According to this analysis Hypothesis 1 predicted that quality of work life influences the turnover intention of employees of an education research hospital. According to the results $H_{1}$ was supported $(\beta=-0.503, p<.01)$. The finding of this study is also consistent with past researches (Mosadeghrad et al., 2011; Zhao et al., 2013; Mohamed Elshahat et al., 2019). Moreover, considering the control variables (marital status, education status, occupation, working hours and income) the quality of work life effects turnover.

Hypothesis $\mathrm{H}_{2}$ states that the job satisfaction mediating effect on the relationship between quality of work life and turnover intention of employees. This hypothesis $\left(H_{2}\right)$ was supported $\left(\beta_{M}=0.015, p<.01 ; \beta_{X}=0.020\right.$, $p$ >.05). Moreover, $H_{2 a}$ predicted that quality of work life influences the job satisfaction. Consistent with previous studies (Morsy and Sabra, 2015; Hadizadeh et al., 2015; Nuari, 2016; Mobaraki et al., 2017; Jahanbani et al., 2018; Srivastava et al., 2019) Hypotheses $H_{2 a}$ supported $(\beta=1.014, p<.01)$. Quality of work life improves job satisfaction thereby helping the organization in retaining their employees (Gurudatt and Gazal, 2015: 12). Similarly, Hypothesis $H_{2 b}$, which states that job satisfaction influences turnover intention of employees and this hypopthesis was supported $(\beta=-0.511, p<.01)$. Moreover, this findings consistent with researches (Tziner et al., 2015; Lu et al., 2017; Chen et al., 2019; Li et al., 2019; Al Sabei et al., 2020).

Hypothesis $H_{3}$ predicted that the gender moderates the mediation of job satisfaction on quality of work life of turnover intention of employees. This hypothesis was supported $\left(\beta_{\mathrm{M} \times \mathrm{Gender}}=-0.421, p<.01\right)$. The study results indicate that gender moderated the relation between quality of work life and job satisfaction $\left(\beta_{\mathrm{X} \times \mathrm{Gender}}=0.488\right.$, $p<.05)$; hence, we conclude that $H_{3 a}$ is supported. On the other hand, $H_{3 b}$ states that the gender moderates the relation between the quality of work life and turnover. This hypothesis was not supported $\left(\beta_{\mathrm{X} \times \mathrm{Gender}}=-\right.$ $0.161, p>.05)$. Finally, $H_{3 c}$ predicted that the gender moderates the relation between the job satisfaction and turnover. According to the results $H_{3 c}$ was supported $\left(\beta_{\mathrm{M} \times \mathrm{Gender}}=-0.303, p<.01\right)$. Moreover, other variables were controlled and it was found that these control variables (marital status, education and working hours) 
effect the female employees turnover intention. In terms of men and women, when the job satisfaction of women decreases, the turnover intention is higher compared to men. Explanation for the gender differences for organizational outcomes may be stem from employees' expectations, work-home related responsibilities or culture.Therefore, when females' expectations are met and responsibilities are shared, they will be more productive in business life.

The findings obtained from this study have some useful results. Healthcare organizations have to prevent turnover intentions to survive. Therefore, it is strongly recommended for healthcare organizations to use these findings. Moreover, this study has some limitations such as conducted among health care employees in Ankara, Turkey. Therefore, future research can investigate this subject in different cities with participants who have different characteristics or include specific variables (eg. culture) to understand gender differences.

\section{References}

Akar, H., \& Üstüner, M. (2017). Turkish adaptation of work-related quality of life scale: Validity and reliability studies. Inonu University Journal of the Faculty of Education, 18(2), 159-176.

Al Sabei, S. D., Labrague, L. J., Miner Ross, A., Karkada, S., Albashayreh, A., Al Masroori, F. \& Al Hashmi, N. (2020). Nursing work environment, turnover intention, job burnout, and quality of care: The moderating role of job satisfaction. Journal of Nursing Scholarship, 52(1), 95-104.

Almalki, M. J., FitzGerald, G., \& Clark, M. (2012a). Quality of work life among primary health care nurses in the Jazan Region, Saudi Arabia: A cross-sectional study. Human Resources For Health, 10(1), 30.

Almalki, M. J., FitzGerald, G., \& Clark, M. (2012b). The relationship between quality of work life and turnover intention of primary health care nurses in Saudi Arabia. BMC Health Services Research, 12(1), 314.

Bashor, C., \& Purnama, C. (2017). Factors affecting performance manager and its impact on competitive advantage: Studies small medium enterprises (SMEs) in the shoes industry Mojokerto East Java Province. Mediterranean Journal of Social Sciences, 8(4), 153-162.

Basim, N., \& Şeşen, H. (2009). Orgutsel adalet algisi-örgütsel vatandaşlik davranişi ilişkisinde iş tatmininin aracilik rolü. 17th Ulusal Yönetim ve Organizasyon Kongresi, Eskişehir, Turkiye.

Black, M. M., \& Holden, E. W. (1998). The impact of gender on productivity and satisfaction among medical school psychologists. Journal of Clinical Psychology in Medical Settings, 5(1), 117-131.

Boles, J. S., Johnston, M. W., \& Hair Jr, J. F. (1997). Role stress, work-family conflict and emotional exhaustion: Inter-relationships and effects on some work-related consequences. Journal of Personal Selling $\mathcal{E}$ Sales Management, 17(1), 17-28.

Boniol, M., McIsaac, M., Xu, L., Wuliji, T., Diallo, K., \& Campbell, J. (2019). Gender equity in the health workforce: analysis of 104 countries (No. WHO/HIS/HWF/Gender/WP1/2019.1). World Health Organization.

Carrillo-García, C., Solano-Ruíz, M. D. C., Martínez-Roche, M. E., \& Gómez-García, C. I. (2013). Job satisfaction among health care workers: The role of gender and age. Revista Latino-Americana De Enfermagem, 21(6), 1314-1320.

Chao, MC., Jou, R.C., Liao, C.C., \& Kuo, C.W. (2015). Workplace stress, job satisfaction, job performance, and turnover intention of health care workers in Rural Taiwan. Asia-Pacific Journal of Public Health, 27(2), $1827-1836$.

Chen, X., Li, R., Zhang, Y., Yang, J., Yao, H., Zhu, S., \& Tan, X. (2019). Moderating role of job satisfaction on turnover intention and burnout among workers in primary care institutions: Across-sectional study. BMC Public Health, 19, 1526.

Corrigall, E. A., \& Konrad, A. M. (2007). Gender role attitudes and careers: A longitudinal study. Sex Roles, 56(11-12), 847-855.

Dayioglu, M. (2000). Labor market participation of women in Turkey. Gender and Identity Construction: Women of Central Asia, Caucasus and Turkey, 44-73. 
D. Kara - N. Potas - F. Seyhan 12/3 (2020) 3027-3041

Dedeoglu, S. (2010). Visible hands - invisible women: Garment production in Turkey, Feminist Economics, and 16(4): $1-32$.

Goksel, I. (2012). The reasons of decreasing trend of female labour force participation in Turkey: The Role of Conservatism. Izmir University of Economics Working Papers 1205.

Goksel, I. (2013). Female labor force participation in Turkey: The role of conservatism. In Women's Studies International Forum, 41 (45-54). Pergamon.

Gurudatt, K., \& Gazal, Y. (2015). Role of (QWL) quality of work life on employee retention in private sector companies. International Journal of Engineering and Management Science, 6(1), 11-15.

Hadizadeh, T. Z., Nourani, S. S., \& Shakeri, M. T. (2015). Relationship between components of quality of work life with job satisfaction among midwives in Mashhad, 2014.

Hayo, B., \& Caris T. (2013) Female labour force participation in the MENA region: The role of identity. Review of Middle East Economics and Finance, 9(3), 271-292.

Health Statistics Yearbook (2018), Republic of Turkey the Ministry of Health, Retrieved from https: //www.saglik.gov.tr/TR,62400/health statistics.

Heidari-Rafat, A., Enayati-Navinfar, A., \& Hedayati, A. (2010). Quality of work life and job satisfaction among the nurses of Tehran University of Medical Sciences, Dena J., 5(3\&4), 28-37.

Heinen, M. M., Van Achterberg, T., Schwendimann, R., Zander, B., Matthews, A., Kózka, M., \& Schoonhoven, L. (2013). Nurse's intention to leave their profession: a cross sectional observational study in 10 European countries. International Journal of Nursing Studies, 50(2), 174-184.

Hsu, M. Y., \& Kernohan, G. (2006). Dimensions of hospital nurses quality of working life, Journal of Advanced Nursing, 54(1), 120-131.

Huang, W. R., \& Su, C. H. (2016). The mediating role of job satisfaction in the relationship between job training satisfaction and turnover intentions. Industrial and Commercial Training, 48(1), 11.

Jahanbani, E., Mohammadi, M., Noruzi, N. N., \& Bahrami, F. (2018). Quality of work life and job satisfaction among employees of health centers in Ahvaz, Iran. Jundishapur Journal of Health Sciences, 10(1), e14381.

Kaitelidou, D., Kontogianni, A., Galanis, P., Siskou, O., Mallidou, A., Pavlaki, S. A., \& Liaropoulos, L. (2012). Conflict management and job satisfaction in paediatric hospitals in Greece. Journal of Nursing Management, 20, 571-578.

Karaalp-Orhan, H. S. (2017). What are the trends in women's labour force participation in Turkey?, European Journal of Sustainable Development, 6(3), 303-303.

Kasraie, S., Parsa S., Hassani M., \& Ghasem-Zadeh, A. (2014). The relationship between quality of work life, job stress, job satisfaction and citizenship behavior in oshnaviyeh hospital's staff. Journal of Patient Safety \& Quality Improvement, 2(2), 77-81.

Kılıç, A. (2008). The gender dimension of social policy reform in Turkey: Towards equal citizenship?. Social Policy \& Administration, 42(5), 487-503.

Lee, Y. W., Dai, Y. T., Park, C. G., \& McCreary, L. L. (2013). Predicting quality of work life on nurse's intention to leave. Journal of Nursing Scholarship, 45(2), 160-168.

Li, N., Zhang, L., Xiao, G., Chen, J., \& Lu, Q. (2019). The relationship between workplace violence, job satisfaction and turnover intention in emergency nurses. International Emergency Nursing, 45, 50-55.

Liu, J., Zhu, B., Wu, J., \& Mao, Y. (2019). Job satisfaction, work stress, and turnover intentions among rural health workers: A cross-sectional study in 11 western provinces of China. BMC Family Practice, 20 (1),9.

Lok, P., \& Crawford, J. (2001). Antecedents of organizational commitment and the mediating role of job satisfaction. Journal of Managerial Psychology,16(8), 594-613. 
Lu, Y., Hu, X. M., Huang, X. L., Zhuang, X. D., Guo, P., Feng, L. F., \& Hao, Y. T. (2017). The relationship between job satisfaction, work stress, work-family conflict, and turnover intention among physicians in Guangdong, China: A cross-sectional study. BMJ Open, 7(5), e014894.

Miao, Y., Li, L., \& Bian, Y. (2017). Gender differences in job quality and job satisfaction among doctors in rural western China. BMC Health Services Research, 17(1), 848.

Mobaraki, H., Meymandi, R.G., Kamali, M., \& Pourbakht, A. (2017). The relationship between quality of work life and job satisfaction among audiologists in Iran. Aud Vest Res, 26(4), 215-222.

Mobley, W. H., Horner, S. O., \& Hollingsworth, A. T. (1978). An evaluation of precursors of hospital employee turnover. Journal of Applied Psychology, 63(4), 408-414.

Mohamed Elshahat, E., Mostafa Shazly, M., \& Abd-Elazeem, H. (2019). Relationship between quality of work life and turnover intention among staff nurses. Egyptian Journal of Health Care, 10(1), 178-193.

Moradi, T., Maghaminejad, F., \& Azizi-Fini, I. (2014). Quality of working life of nurses and its related factors. Nursing and Midwifery Studies, 3(2), e19450.

Morsy, S.M., \& Sabra, H.E. (2015). Relation between quality of work life and nurses job satisfaction at Assiut University Hospitals. Al-Azhar Assiut Medical Journal, 13(1), 163-171.

Mosadeghrad, A. M. (2013). Quality of working life: an antecedent to employee turnover intention. International Journal of Health Policy and Management, 1(1), 43-50.

Newman, A., Nielsen, I., Smyth, R., \& Hooke, A. (2015). Examining the relationship between workplace support and life satisfaction: The mediating role of job satisfaction. Social Indicators Research, 120(3), 769-781.

Nuari, N.A. (2016). Quality of work life and job satisfaction of nurses in Amelia Hospital Pare. Jurnal Ners dan Kebidanan, 3(1), 1-7.

Oh, S., \& Kim, H. (2019). Turnover intention and its related factors of employed doctors in Korea. International Journal of Environmental Research and Public Health, 16(14), 2509-2516.

O'Neil, M.L., \& Bilgin. M.H. (2013). Religion as a factor influencing women's decisions to work. Journal of International Women's Studies, 14(3), 163-173.

Paillé, P. (2011). Stressful work, citizenship behaviour and intention to leave the organization in a high turnover environment: Examining the mediating role of job satisfaction. Journal of Management Research, 3(1), 1-14.

Rubel, M. R. B., \& Kee, D. M. H. (2015). High commitment compensation practices and employee turnover intention: Mediating role of job satisfaction. Mediterranean Journal of Social Sciences, 6(6S4), 321-332.

Sandrick, K. (2003). Putting the emphasis on employees. Trustee: The Journal for Hospital Governing Boards, 56(1), 6-10.

Saraji, G. N., \& Dargahi, H. (2006). Study of quality of work life (QWL). Iranian Journal of Public Health, 8-14.

Sirgy, M., Efraty, D., Siegel, P., \& Lee, D. (2001). A new measure of quality of work life (QWL) based on need satisfaction and spillover theories. Social Indicators Research, 55(3), 241-302.

Srivastava S., Misra, R., \& Madan, P. (2019). The saviors are also humans': Understanding the role of quality of work life on job burnout and job satisfaction relationship of Indian doctors. Journal of Health Management, 21(2), 210-229.

Steinmetz, S., de Vries, D. H., \& Tijdens, K. G. (2014). Should I stay or should I go? The impact of working time and wages on retention in the health workforce. Human Resources for Health, 12(1), 23.

Tarcan, G. Y., Tarcan, M., \& Top, M. (2017). An analysis of relationship between burnout and job satisfaction among emergency health professionals. Total Quality ManagementEBusiness Excellence, 28(11-12), 13391356. 
D. Kara - N. Potas - F. Seyhan 12/3 (2020) 3027-3041

Thakur, R., \& Sharma, D. (2019). A study of impact of quality of work life on work performance. Management and Labour Studies, 44(3), 326-344.

Turkish Statistical Institute (2018). Labor Statistics. Turkish Statistical Institute (TUIK), Retrieved from http://www.tuik.gov.tr

Tziner, A., Rabenu, E., Radomski, R., \& Belkin, A. (2015). Work stress and turnover intentions among hospital physicians: The mediating role of burnout and work satisfaction. Revista de Psicología del Trabajo y de las Organizaciones, 31(3), 207-213.

Van Laar, D., Edwards, J. A. \& Easton, S. (2007). The work related quality of life scale for healthcare workers. Journal of Clinical Nursing. 3(60), 325-33.

World Economic Forum. (2020). Global gender gap report. Geneva: World Economic Forum.

Zhao, X., Sun, T., Cao, Q., Li, C., Duan, X., Fan, L., \& Liu, Y. (2013). The impact of quality of work life on job embeddedness and affective commitment and their coeffect on turnover intention of nurses, Journal of Clinical Nursing, 22(5-6),780-788. 